\title{
Differences in Erythrocyte Magnesium Levels between Men with Schizophrenia Treated with Risperidone and Haloperidol in Prof. Dr. M Ildrem Psychiatric Hospital Medan
}

\author{
Ihsan Fadhilah (D), Bahagia Loebis (i), Muhammad Surya Husada*(i), Nazli Mahdinasari Nasution (iD), Elmeida Effendy (D) \\ Department of Psychiatry, Faculty of Medicine, University of North Sumatra, Medan, Indonesia
}

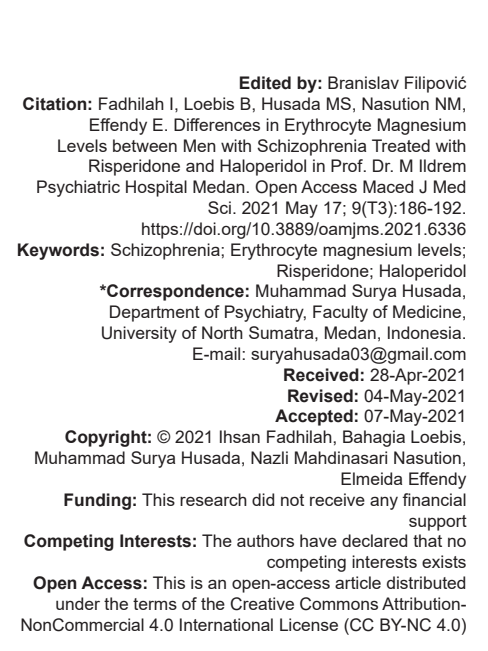

Abstract

BACKGROUND: Schizophrenia according to the world health organization is one of the top ten causes of disability in developed countries around the world. Because of the severity, chronicity, and prevalence of schizophrenia, it has a very large economic burden. Magnesium is a micronutrient needed by the body which can affect mental health. Erythrocyte magnesium levels are considered more sensitive than serum magnesium levels to reflect intracellular magnesium status.

AIM: The objective of the study was to determine the differences in erythrocyte magnesium levels between men with schizophrenia who received risperidone and haloperidol treatment at Prof. Dr. M Ildrem Psychiatric Hospital, Medan.

METHODS: This study is an intention to treat and is an experimental pre-test and post-test that compares two groups, namely the intervention group and the control group. The sampling method is non-probability sampling with a consecutive sampling type. The research was conducted at Prof. Dr. M. Ildrem Psychiatric Hospital Medan between July and October 2019. The subjects of the study were 60 men with schizophrenia, namely, 30 who received risperidone and 30 who received haloperidol.

RESULTS: There was a difference in the levels of male erythrocyte magnesium with schizophrenia who received risperidone and haloperidol between the initial week and the third week with a value of $p=0.007$. Where there was higher increase in the haloperidol group which showed a significant difference, namely, $p<0.05$.

CONCLUSION: The increase in magnesium levels will improve the symptoms of schizophrenia where magnesium activity decreases glutamate release associated with $\mathrm{N}$-Methyl D-Aspartate receptors and results in the activity of the gamma-aminobutyric acid-ergic system.

\section{Introduction}

Schizophrenia is a psychotic disorder that is generally characterized by psychopathological damage that involves cognition, emotion, perception, and behavioral aspects and manifests in the patient and affects the course of the disease, which is usually severe and long-lasting [1]. The world health organization has marked it as one of the top ten causes of disability in developed countries around the world. Because of the severity, chronicity, and prevalence of schizophrenia, it has a very large economic burden [2]. According to data from the Ministry of Health of the Republic of Indonesia, $90 \%$ of people with schizophrenia are the most mental disorders who experience shackling because research shows that the main reason for shackling in more than $90 \%$ of cases is because of schizophrenia symptoms such as impaired perception, thinking that causes violent behavior by people with the schizophrenia. If examined more deeply, family shackling is primarily intended to provide protection, both for sufferers and other people [3].
Micronutrient deficiency is associated with psychiatric disorders. Magnesium is a micronutrient needed by the body which can affect mental health [4]. The body contains typically about 21-28 g of magnesium. About $53 \%$ of total body magnesium is stored in bone, $27 \%$ in muscle, $19 \%$ in soft tissue, $0.5 \%$ in erythrocyte, and $0.3 \%$ in serum. Erythrocyte magnesium levels are considered more sensitive than serum magnesium levels to reflect intracellular magnesium status [5], [6]. The concentration of magnesium in erythrocytes in general appears to be higher than the concentration of magnesium in serum. Magnesium levels can be measured by various methods such as titration, colorimetry/spectrophotometry, flame emission spectroscopy, atomic absorption spectrophotometry, and ion-selective electrodes. Normal erythrocyte magnesium levels measured by atomic absorption spectrophotometry were in the range of 3.64-5.56 $\mathrm{mEq} / \mathrm{l}$ [6]. Significantly reduced intracellular magnesium levels are characteristic for mental disorders such as schizophrenia, epilepsy, hypothalamic syndrome, hearing loss, and fine motor disorders. Increased extracellular magnesium is known 
to decrease glutamate release and the capacity of neurotransmitters to bind to $\mathrm{N}$-Methyl D-Aspartate (NMDA) receptors [7].

The basic theories of schizophrenia include biochemical hypotheses such as: Dopaminergic, serotonergic, and glutamate. Among them, the dopaminergic theory predominates regarding the symptoms of psychosis due to excessive dopaminergic stimulation in the structures of the limbic system. In recent years, it has been observed that there is impaired magnesium among schizophrenic patients. It is generally accepted that magnesium in erythrocytes can participate in the mechanisms of action of drugs used in schizophrenia (e.g., haloperidol and risperidone). Increased magnesium levels after administration of antipsychotic drugs can modulate the activity of metabotropic glutamate receptors, such as mGluR5 (glutamate five metabotropic receptors) and mGluR2 (glutamate two metabotropic receptors), and possibly mGluR7 (glutamate metabotropic receptor 7) [8].

Both plasma magnesium and erythrocyte levels appear to be impaired in various psychiatric disorders such as major depression, drug dependence, and including schizophrenia. Several different research results have been reported regarding the concentration of magnesium in blood plasma with cellular magnesium in people with schizophrenia. In the Chugh and Gattaz study found high levels of magnesium in plasma and cerebrospinal fluid in people with schizophrenia, while in the study of Yassa et al., Levine et al., Kirov et al., and Kanofsky et al., they found decreased plasma magnesium levels and cerebrospinal fluid in people with schizophrenia. This is due to the heterogeneity of the patient and there are many forms of schizophrenia [7]. Studies regarding erythrocyte magnesium levels in people with schizophrenia are very limited. This study is the first study conducted in Indonesia, especially in North Sumatra, to examine differences in erythrocyte magnesium levels in men with schizophrenia who received risperidone and haloperidol therapy. Therefore, to determine the sample size, a preliminary study was conducted by recruiting 20 subjects, namely, ten subjects who received risperidone therapy and ten subjects who received haloperidol therapy.

\section{Methods}

This study is intention to treat and is an experimental pre-test and post-test that compares two groups, namely, the intervention group and the control group. Group I: A group of men with schizophrenia who received risperidone treatment. Group II: A group of men with schizophrenia who received haloperidol treatment. The sampling method was non-probability sampling with a consecutive sampling type. The study was conducted at the inpatient installation of Prof. Dr. M. Ildrem Psychiatric Hospital Medan in July-October 2019. The study was conducted with 60 research subjects, namely, 30 subjects who received risperidone and 30 subjects who received haloperidol. The inclusion criteria in this study were: Men with schizophrenia who met the Pedoman Penggolongan dan Diagnosis Gangguan Jiwa di Indonesia III (PPDGJ-III) criteria in Prof. Moh. Ildrem Psychiatric Hospital Medan North Sumatra, Schizophrenia active phase schizophrenia, Cooperative and willing as research subjects, age 15-35 years, minimum junior high school education, has a total score of PANSS 90-150, length of illness $<5$ years, normal body mass index, and erythrocyte magnesium levels $<3.64 \mathrm{mEq} / \mathrm{l}$. The exclusion criteria in this study were using antihypertensive drugs, heart medications, antibiotics, and antacids, having general medical illnesses, using illegal substances, smoking, and consuming alcohol.

\section{Procedure}

Sampling data were preceded by structured interviews using the MINI ICD-10 and diagnostic guidelines based on PPDGJ-III, then continued by screening using inclusion and exclusion criteria. Patients who met the inclusion criteria and did not have the exclusion criteria were asked for consent to participate in the study after obtaining informed consent. So patients were asked to sign the consent to be the subject of this study.

Blood samples were taken from male patients with schizophrenia before receiving risperidone and haloperidol treatment at the same hour, before activity and before meals. Blood samples were taken at 08.00 09.00 a.m, blood samples were taken through the median cubital vein as much as $7 \mathrm{~mL}$ and collected into a vacuum tube with lithium anticoagulant heparin spray. Then, the blood sample was immediately taken to the laboratory to measure the erythrocyte magnesium level ( $<2 \mathrm{~h}$ after blood collection) in a closed transport container with a temperature of $18-28^{\circ} \mathrm{C}$. For the $1^{\text {st }}$ time, blood was centrifuged at $2000 \mathrm{~g}$ for $15 \mathrm{~min}$ to separate serum/plasma. Separate clear serum/plasma from red blood cells with a Pasteur pipette into another tube that has been labeled according to the sample. Then, the erythrocyte cell washing procedure was carried out with $0.9 \%$ sodium chloride $(0.9 \% \mathrm{NaCl})$ and then centrifuged at a speed of $2000 \mathrm{~g}$ for $10 \mathrm{~min}$. Then, the supernatant was discarded and carried out a 1: 30 dilution with $0.3 \mathrm{M}$ hydrochloric acid containing $0.5 \%$ lanthanum chloride (w/v). Measurement of erythrocyte magnesium levels was carried out using atomic absorption spectrometry [6], [9]. Then, an equivalent dose of risperidone and haloperidol was performed. Based on a study conducted by Leutcht et al. in Germany in 2015 which examined the equivalent dose of an antipsychotic that received 75 randomized, 
double-blind, dose flexibility studies involving 16,555 subjects in cases of schizophrenia, it found that the equivalent of $1 \mathrm{mg}$ olanzapine risperidone is equivalent to 0.38 risperidone and 0.74 haloperidol. Therefore, it can be concluded that $1 \mathrm{mg}$ of risperidone is equivalent to $1.94 \mathrm{mg}$ of haloperidol [10].

In this study, both the men with schizophrenia who received risperidone treatment and the subjects in the men with schizophrenia who received haloperidol treatment were given a flexible-dose by first using the equivalent dose of risperidone and haloperidol. The Group I consisted of men with schizophrenia who received divided doses of risperidone starting with a dose of $2 \mathrm{mg}$ for men with schizophrenia who had never received treatment or the last dose that had been used. Then, the PANSS score was measured every 3 days if the PANSS score had not reached a response, then the risperidone dose was increased by $1 \mathrm{mg} /$ day until a response occurred.

Group II was men with schizophrenia who received haloperidol therapy in divided doses starting with a dose of $3.88 \mathrm{mg}$ for men with schizophrenia who had never received treatment or the last dose that had been used. Then the PANSS score measurement is carried out every 3 days if the PANSS score has not reached a response, and then the risperidone dose is increased by $1.94 \mathrm{mg} /$ day, until a response occurs on research subjects.

If side effects such as acute dystonia occur during treatment, an injection of diphenhydramine $10 \mathrm{mg}$ intramuscular can be given a maximum of 30 mg a day. If extrapyramidal symptoms occur during treatment, trihexyphenidyl anticholinergic therapy is given at a dose of 4-6 mg/day/orally in divided doses, a maximum of $15 \mathrm{mg}$. If a side effect of akathisia occurs, the subject will be given 2 mg of lorazepam, a maximum of $6 \mathrm{mg}$ in divided doses, and a maximum of $6 \mathrm{mg}$ in divided doses.

After all of the blood samples and the subject's data were filled, the blood samples were collected then processed and analyzed the data. This study has received approval from the Research Ethics Committee at the Faculty of Medicine, University of North Sumatra, Medan.

\section{Statistical analysis}

Data were analyzed using SPSS version 21. Test analysis was carried out on variable levels of magnesium erythrocytes of men with schizophrenia who received risperidone and haloperidol. Data normality test was performed using the Shapiro-Wilk test for samples less than or equal to 50 . If the data are normally distributed, followed by an independent t-test at week 3 erythrocyte magnesium levels between the groups receiving risperidone and haloperidol. However, on the contrary, if it is not normally distributed, an effort will be made to normalize the data by transforming the data with $\log 10$, and if the effort to normalize the data is unsuccessful, a Mann-Whitney U-test will be carried out. Displayed in the form of mean and standard deviation if normally distributed and if not normally distributed then the data will be presented with the Median (minimum-maximum). For erythrocyte magnesium levels at week 3 , if the data are normally distributed, it is followed by an independent t-test. On the other hand, if it is not normally distributed, an effort will be made to normalize the data by transforming the data with $\log 10$, and if the effort to normalize the data is not successful, then the Wilcoxon test will be carried out [11]. The difference in magnesium levels of male erythrocytes with schizophrenia who received risperidone and haloperidol will be determined with a value of $p<0.05$

\section{Results}

The characteristics of the subjects of this study are shown in Table 1 that the mean and standard deviation for age in males with schizophrenia in the group receiving risperidone was $28.33 \pm 5.26$, while the mean and standard deviation for age in males with schizophrenia in the group got haloperidol $27.93 \pm 4.48$. Based on education for the junior secondary education level, most men with schizophrenia in the group who received haloperidol were nine people (30\%). At the high school education level, the majority of males with schizophrenia were in the group who received

Table 1: Demographic characteristics of research subjects

\begin{tabular}{|c|c|c|c|}
\hline Characteristics & $\begin{array}{l}\text { Male with } \\
\text { schizophrenia } \\
\text { treated with } \\
\text { risperidone }(n=30)\end{array}$ & $\begin{array}{l}\text { Male with } \\
\text { schizophrenia } \\
\text { treated with } \\
\text { haloperidol }(n=30)\end{array}$ & $p$-value \\
\hline \multicolumn{4}{|l|}{ Age } \\
\hline Mean \pm s.d & $28.33 \pm 5.26$ & $27.93 \pm 4.48$ & $0.752^{\mathrm{d}}$ \\
\hline \multicolumn{4}{|l|}{ Education level } \\
\hline Junior high school & $7(23.3 \%)$ & $9(30 \%)$ & \multirow[t]{2}{*}{$0.731^{\mathrm{a}}$} \\
\hline Senior high school & $16(53.4 \%)$ & $13(43.3 \%)$ & \\
\hline University & $7(23.3 \%)$ & $8(26.7 \%)$ & \\
\hline \multicolumn{3}{|l|}{ Occupational status } & \multirow[t]{3}{*}{$1.000^{\mathrm{b}}$} \\
\hline Employed & $9(30 \%)$ & $10(33.3 \%)$ & \\
\hline Unemployed & $21(70 \%)$ & $20(66.7 \%)$ & \\
\hline \multicolumn{4}{|l|}{ Marital status } \\
\hline Married & $9(30 \%)$ & $14(46.7 \%)$ & \multirow[t]{2}{*}{$0.288^{\mathrm{b}}$} \\
\hline Unmarried & $21(70 \%)$ & $16(53.3 \%)$ & \\
\hline \multicolumn{4}{|l|}{ Length of sickness (years) } \\
\hline$<1$ & $17(56.7 \%)$ & $18(60 \%)$ & \multirow[t]{3}{*}{$0.906^{\mathrm{c}}$} \\
\hline $1-<2$ & $10(33.3 \%)$ & $8(26.7 \%)$ & \\
\hline $2-<3$ & $3(10 \%)$ & $4(13.3 \%)$ & \\
\hline \multicolumn{4}{|l|}{ Body mass index } \\
\hline Mean \pm s.d & $21.89 \pm 1.78$ & $21.69 \pm 1.29$ & $0.621^{d}$ \\
\hline \multicolumn{4}{|l|}{ Socioeconomic level } \\
\hline Low class & $16(53.3 \%)$ & $17(56.7 \%)$ & \multirow[t]{3}{*}{$0.748^{\circ}$} \\
\hline Middle class & $9(30 \%)$ & $9(30 \%)$ & \\
\hline High class & $5(16.7 \%)$ & $4(13.3 \%)$ & \\
\hline \multicolumn{4}{|l|}{ Initial erythrocyte magnesium level } \\
\hline Mean \pm s.d & $2.55 \pm 0.46$ & $2.47 \pm 0.45$ & $0.508^{d}$ \\
\hline \multicolumn{4}{|l|}{ Ethnicity } \\
\hline Batak & $18(60 \%)$ & $17(46.7 \%)$ & \multirow{2}{*}{$1.000^{\mathrm{b}}$} \\
\hline Java and Malay & $12(40 \%)$ & $13(43.3 \%)$ & \\
\hline PANSS score & $109.50(93-132)$ & $113(95-132)$ & $0.510^{\circ}$ \\
\hline \multicolumn{4}{|l|}{ Early week } \\
\hline Median (Minimum -Maximum ) & & & \\
\hline
\end{tabular}


risperidone as many as 16 people (53.4\%). At the tertiary level, the highest number of men with schizophrenia was in the group that received haloperidol as many as eight people $(26.7 \%)$. Based on the status of work, the group that did not work mostly was the group that received risperidone as many as 21 people $(70 \%)$, and the group that worked the most in the group that got haloperidol was ten people $(33.3 \%)$. Based on the marital status, the most unmarried group was in the risperidone group as many as 21 people $(70 \%)$, and the most married group was in the group that got haloperidol as many as 14 people $(46.7 \%)$. Based on the length of illness in the subject group $<1$ year, the most in the group that received haloperidol were 18 people $(60 \%)$. In the duration of illness, subjects $1-<2$ years were mostly in the group that received risperidone as many as ten people (33.3\%). In the duration of illness, subjects $2-<3$ years were mostly in the group that received haloperidol as many as four people (13.3\%). Based on the average body mass index of research subjects in the group receiving risperidone of $21.89 \pm 1.78 \mathrm{~kg} / \mathrm{m}^{2}$ and those receiving haloperidol of $21.69 \pm 1.29 \mathrm{~kg} / \mathrm{m}^{2}$ with a value of $p=0.621$. Based on the highest socioeconomic level, the group that received haloperidol was 17 (56.7\%). In the middle class, the majority is the same in both groups, namely, nine people (30\%). Most high-class socio-economic status was in the group who received risperidone as many as five people $(16.7 \%)$, with a value of $p=0.748$.

Based on the mean magnesium levels in the early week group that received risperidone was $2.55 \pm$ $0.46 \mathrm{mEq} / \mathrm{l}$, while the group receiving haloperidol was $2.47 \pm 0.45 \mathrm{mEq} / \mathrm{l}$ with a value of $p=0.508$. Based on the highest number of Batak ethnic groups in the group that received risperidone, 18 people $(60 \%)$. Based on Javanese ethnicity, the largest number of groups receiving haloperidol was 11 people (36.7\%). Based on the most Malay ethnicity, the group that received risperidone was three people (10\%).

Based on the PANSS Score Week 0, it was found that the median (minimum-maximum) of men with schizophrenia in the group who received risperidone was 109.50 (93-132), while the median (minimummaximum) of men with schizophrenia was in the group who received haloperidol 113 (95-132) with $p=0.510$.

Table 2 shows that the total PANSS score of men with schizophrenia who received risperidone and haloperidol treatment at $3^{\text {rd }}$ week with a value $p=0.089$.

Figure 1 shows the PANSS score in the two groups receiving risperidone treatment and those receiving haloperidol shows almost the same graph and

Table 2: Total PANSS score of men with schizophrenia who received risperidone and haloperidol at $3^{\text {rd }}$ week

\begin{tabular}{llll}
\hline Group & Mean (s.b) & p-value & $\begin{array}{l}\text { Mean differences } \\
(\mathrm{Cl} 95 \%)\end{array}$ \\
\hline Risperidone $(\mathrm{n}=30)$ & $37.60 \pm 3.03$ & 0.089 & $1.53(-0.24-3.30)$ \\
Haloperidol $(\mathrm{n}=30)$ & $36.07 \pm 3.78$ & & \\
\hline Independent t-test $\mathrm{p}<0.05$. & & &
\end{tabular}

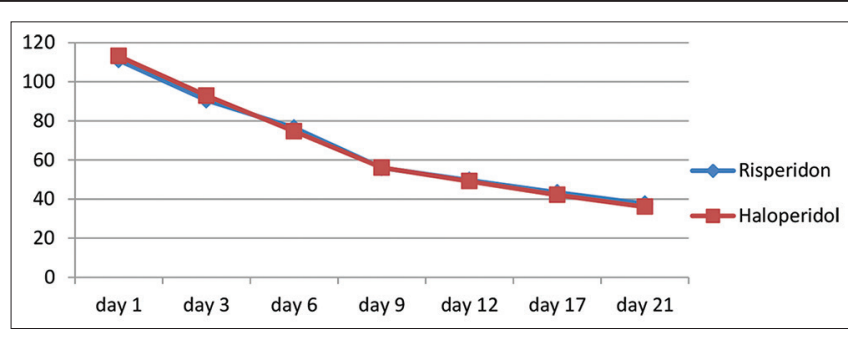

Figure 1: Observation of the mean PANSS score in the two groups of subjects who received risperidone and haloperidol treatment risperidone and haloperidol from the initial week to $3^{\text {rd }}$ week

shows a decrease in the PANSS score in both groups so that it can be said that each group in this study found treatment progress based on the PANSS score.

For the dose equivalence of the drugs risperidone and haloperidol at week 3 , the median (minimum-maximum) of men with schizophrenia in the haloperidol-to-risperidone-3-week equivalent dose group was $7.80(7.80-11.70)$ where 17 subjects received a dose of $4 \mathrm{mg}$ and 13 subjects received a dose of $6 \mathrm{mg}$ while the median (minimum-maximum) dose of haloperidol week 3 was $7.50(7.50-12.0)$ where 18 subjects received a dose of $7.5 \mathrm{mg}$ and 12 subjects received a dose 12 with $p=0.168$.

Table 3: Description of the $3^{\text {rd }}$ week drug dose between men with schizophrenia who received risperidone and haloperidol

\begin{tabular}{lll}
\hline Group & $\begin{array}{l}\text { Median } \\
\text { Minimum - Maximum }\end{array}$ & p-value \\
\hline $\begin{array}{l}\text { The equivalent dose of } \\
\text { haloperidol to risperidone }(n=30)\end{array}$ & $7.80(7.80-11.70)$ & 0.168 \\
Haloperidol dose $(n=30)$ & $7.50(7.50-12.0)$ & \\
\hline Mann-Whitney U-test $p>0.05$. &
\end{tabular}

Figure 2 shows that the mean dose of the equivalent dose of risperidone to haloperidol and the dose of haloperidol during 3 weeks of treatment, it is seen that the equivalence of the equivalence between the two drug groups can be found in the initial week to week 3.

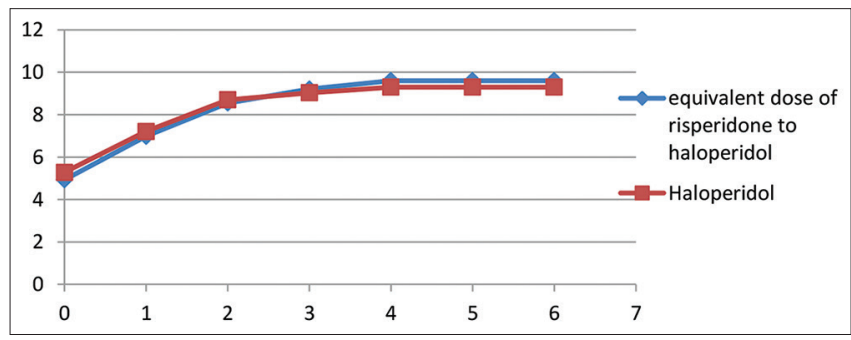

Figure 2: Observation mean dose in the two groups of men with schizophrenia who received risperidone and haloperidol treatment from the initial week to $3^{\text {rd }}$ week

In Table 4, it can be seen that the median (minimum-maximum) magnesium level in the men with schizophrenia in the group who received risperidone at

Table 4: Mann-Whitney U-test on erythrocyte magnesium levels of men with schizophrenia who received risperidone and haloperidol at $3^{\text {rd }}$ week

\begin{tabular}{llc}
\hline Group & $\begin{array}{l}\text { Median } \\
\text { Minimum - Maximum }\end{array}$ & $\mathrm{p}$-value \\
\hline Risperidone $(n=30)$ & $4,44(3,43-5,33)$ & 0.007 \\
Haloperidol $(n=30)$ & $4,91(3,73-5,51)$ &
\end{tabular}


the end of week 3 was 4.44 (3.43-5.33) mEq/l while the group that received haloperidol of 4.91 (3.73-5.51) $\mathrm{mEq} / \mathrm{l}$ with a value of $p=0.007$ where there was a significant difference in magnesium levels in men with schizophrenia between the group that received risperidone and the group that received haloperidol at the end of the $3^{\text {rd }}$ week.

\section{Discussion}

Based on the demographic characteristics of the study sample, the age of men with schizophrenia in the risperidone group was $28.33 \pm 5.26$, while the mean and standard deviation for age in men with schizophrenia in the haloperidol group was $27.93 \pm$ 4.48. This is consistent with the American Psychiatric Association's suggestion that the psychotic features of schizophrenia usually appear between late adolescence and mid-30s, onset before adolescence is rare. The peak age at onset for the first psychotic episode is in the early to mid-20s for men and in the late $20 \mathrm{~s}$ for women. The onset may be sudden or dangerous, but most individuals show a slow and gradual progression of clinically significant signs and symptoms. In a cohort study conducted in Melbourne in 2011 by Gogtay on subjects at high risk of schizophrenia, the mean age of onset was $19 \pm 3.5$ years in $58 \%$ of men. In a study by Buoli and colleagues in Milan, Italy in 2012, it was stated that the mean age of onset of schizophrenia was $23.22 \pm 5.97$ years [12], [13], [14].

In the study, the education level of subjects with junior high school education was seven people (23.3\%) in men with schizophrenia in the risperidone group and men with schizophrenia in the haloperidol group as many as nine people (30\%). At the high school education level, 16 people (53.4\%) received risperidone, and 13 people received haloperidol $(43.3 \%)$. At the university education level, seven people received risperidone (23.3\%), while the group that received haloperidol was eight people $(26.7 \%)$. This is consistent with the study of Huang et al. in Shanghai, China in 2018 showed the highest level of high school education among people with schizophrenia, namely, 39.5\% ( $n=43$ people), university education $34.8 \%$ ( $n=38$ people), and junior high school $25.7 \%$ ( $n=28$ person) [15].

In this study, the occupational status of the group who received risperidone did not work as many as 21 people $(70 \%)$, while those who received haloperidol were as many as 20 people $(66.7 \%)$. The group received risperidone for work as many as nine people $(30 \%)$, while in the group who received haloperidol for work ten people $(33.3 \%)$. This is following the study of Huang et al. in 2015 in Shanghai showing 46 people with schizophrenia who do not work (42.2\%) and 37 people $(33.9 \%)$ work. A study by De Pinho et al. in 2016 in Portugal also showed that more people with schizophrenia who did not work were 82 people $(29.1 \%)$ compared to those who worked only 26 people $(9.2 \%)$ and 174 people who could not work (61.7\%) [15], [16].

In this study, for the marital status of the group that received risperidone, nine people were married (30\%), while ten people received haloperidol (46.7\%). For unmarried marital status, 21 people $(70 \%)$ received risperidone while 16 people received haloperidol (53.3\%). This is following the study of Huang et al. in 2015 in Shanghai that people with schizophrenia are more often unmarried than married, namely, those who are not married, 61 people $(56 \%)$, and married 23 people (21.1\%). A study by De Pinho et al. in 2016 in Portugal also showed that there were more people with schizophrenia who were not married, namely, 190 people $(67.4 \%)$, married 40 people (14.2\%), and divorced 52 people (18.4\%) [15], [16].

For the length of illness subject $<1$ year, as many as 17 people (56.7\%) in men with schizophrenia in the group who received risperidone and in men with schizophrenia in the group who received haloperidol as many as 18 people $(60 \%)$. In the duration of illness, subjects $1-<2$ years were ten people $(33.3 \%)$ who received risperidone and in the group receiving haloperidol as many as eight people (26.7\%). In the duration of illness, the subjects were $2-<3$ years, for the group that received risperidone as many as three people $(10 \%)$, while the group that received haloperidol was four people (13.3\%).

For the socio-economic level, the group that received low-grade risperidone was 16 people (53.3\%), while the group that received haloperidol was 17 $(56.7 \%)$. The middle class in the group that received risperidone was nine people $(30 \%)$, and the group that received haloperidol was nine people (30\%). The high class in the group that received risperidone was five people $(16.7 \%)$, and in the group who received haloperidol were four people (13.3\%). This study is different from the study of Huang et al. in 2015 in Shanghai, showing 29 people with schizophrenia who have lower class socioeconomic status (26.6\%), 62 people $(56.9 \%)$ middle class, and 18 high-class people. people $(16.5 \%)$. This difference is probably because this study was conducted in Indonesia, whereas the previous study was conducted in Shanghai with a different socioeconomic level [15].

For the ethnic groups in this study, there were 18 people $(60 \%)$ who received the risperidone group, 17 people $(56.7 \%)$ received haloperidol for the JavaneseMalay tribe in the group that received risperidone as many as 12 people (40\%), and in the group that received haloperidol as many as 13 people (43.3\%).

For the dose equivalence of the drugs risperidone and haloperidol at week 3 , the median (minimum-maximum) of men with schizophrenia in the haloperidol to risperidone week 3 equivalent dose group was $7.80(7.80-11.70)$ while the median 
(minimum-maximum) the dose of haloperidol week 3 was 7.50 (7.50-12.0), it was found that $p=0.168$. It can be concluded that the dose of the drug at week 3 was not significantly different for the two groups.

For the PANSS score for week 0 , the median (minimum-maximum) of men with schizophrenia in the group receiving risperidone was 109.50 (93-132), while the median (minimum-maximum) of men with schizophrenia in the group receiving haloperidol was 113 (95-132) with a value of $p=0.510$, there was no significant difference in the PANSS score week 0 between the two groups.

In this study, there was a very significant difference in the PANSS score week 0 and week 3 in men with schizophrenia who received risperidone with a value of $p<0.01$. And also found a very significant difference in PANSS scores week 0 and week 3 in men with schizophrenia who received haloperidol with a value of $p<0.01$. There was no significant difference in the PANSS score week 3 in men with schizophrenia who received risperidone and haloperidol with a value of $p=0.089$.

In this study, the mean erythrocyte magnesium level in the group before receiving risperidone was $2.55 \pm$ $0.46 \mathrm{mEq} / \mathrm{l}$, while the group before receiving haloperidol was $2.47 \pm 0.45 \mathrm{mEq} / \mathrm{l}$ where there was a decrease in magnesium levels people with schizophrenia. This is by the study of Nechifor in 2004 in Romania, explaining that there was a decrease in erythrocyte magnesium levels in people with schizophrenia compared to the healthy group with $p<0.01$, where the decrease in erythrocyte magnesium levels in people with schizophrenia was not well understood [7]

In this study, it was found that the median (minimum-maximum) erythrocyte magnesium level in the men with schizophrenia in the group who received risperidone at the end of week 3 was 4.44 (3.43-5.33) $\mathrm{mEq} / \mathrm{l}$ while the group that received haloperidolamounted to 4.91 (3.73-5.51) $\mathrm{mEq} / \mathrm{l}$ with a value of $p=0.007$ where there was a significant difference in erythrocyte magnesium levels of men with schizophrenia between the risperidone group and the haloperidol group at the end of week 3 . This is by a study by Nechifor in 2004 in Romania, with the administration of haloperidol $8 \mathrm{mg} /$ day orally for 21 days or risperidone $6 \mathrm{mg} /$ day orally for 21 days, the erythrocyte magnesium concentration significantly increased from 4.82. $\pm 0.31 \mathrm{mg} / \mathrm{dl}$ before treatment, after administration of haloperidol it became $5.46 \pm 0.19 \mathrm{mg} / \mathrm{dl}$ with $\mathrm{p}<0.05$ and after administration of risperidone it became $5.28 \pm 0.21 \mathrm{mg} / \mathrm{dl}$ with $p<0.05$, where there was a higher increase in the haloperidol group [7].

Magnesium homeostasis is regulated by the intestines, bones, and kidneys. Magnesium like calcium is absorbed in the intestines and stored in bone minerals, and excess magnesium is excreted by the kidneys and feces. Magnesium is mainly absorbed in the small intestine, although some are also taken up through the large intestine. The majority of magnesium is absorbed in the ileum and jejunum by passive paracellular mechanisms. A small, but important, regulation of magnesium is transported through transcellular transporter transient receptor potential channel melastatin members (TRPM) 6 and TRPM7 which also play an important role in intestinal calcium absorption. Of the total magnesium consumed, only about $24-76 \%$ is absorbed in the intestine and the rest is eliminated in the feces [17]. According to a study by Severance et al. in 2015 in the United States in this study, it was explained that people with schizophrenia are closely related to gastrointestinal disorders, biochemical and physiological evidence supporting gastrointestinal etiology for psychiatric diseases has been accumulating since 1860. People with schizophrenia are found that there is hyperactivity of 5-hydroxy-L-tryptophan (5-HTP) which is formed by enterochromaffin cells in the intestine which causes hyperactivity of serotonin and dopamine. Therefore, the hyperactivity of 5-HTP will affect sensorymotor function and secretion of fluid and mucus, thereby affecting magnesium absorption in the ileum and jejunum [18], [19], [20].

Typical and atypical antipsychotic drugs treat the hyperactivity of 5-HTP thereby reducing dopamine and serotonin hyperactivity, so that motor-sensory function, fluid secretion, and mucus return to normal and increase magnesium absorption [20].

In this study, there was a difference in the increase in magnesium levels after the administration of risperidone and haloperidol for 3 weeks where haloperidol increased magnesium levels more than risperidone. This may be due to differences in the affinity of the two drugs; haloperidol is a class of drugs that have a strong affinity for dopamine D1 and D2 receptors, whereas risperidone binds strongly to dopamine D2 receptors and $5 \mathrm{HT} 2 \mathrm{~A}$ receptors. Strong risperidone affinity for $5 \mathrm{HT}-2 \mathrm{~A}$ receptors will affect 5 HT-2 receptors in the gut which function as electrolyte transport in the gut whereas haloperidol does not affect 5 HT-2 receptors in the gut [19], [20], [21].

This increase in magnesium levels will improve the symptoms of schizophrenia where magnesium activity decreases glutamate release associated with NMDA receptors and results in the activity of the gamma-aminobutyric acid-ergic system [7], [8].

The advantage of this study is to measure the magnesium level in erythrocytes where the magnesium level in erythrocytes is considered more sensitive than the serum magnesium level to reflect intracellular magnesium status.

The limitation of this study is that this study also did not see an increase in erythrocyte magnesium levels every week, to see when a significant increase in erythrocyte magnesium levels began after the administration of risperidone and haloperidol. 


\section{References}

1. Departemen Kesehatan Republik Indonesia. Pedoman Penggolongan dan Diagnosis Gangguan Jiwa di Indonesia III (PPDGJ-III). Jakarta: Departemen Kesehatan Republik Indonesia; 1993. https://doi.org/10.6066/jtip.2013.24.2.121

2. Kirkpatrick B, Miller B, García-Rizo C, Fernandez-Egea E. Schizophrenia: A systemic disorder. Clin Schizophr Relat Psychoses. 2014;8(2):73-9. https://doi.org/10.3371/csrp. kimi.031513

\section{PMid:23518782}

3. Menteri Kesehatan Republik Indonesia, Peraturan Menteri Kesehatan Republik Indonesia Nomor 54 Tahun 2017 Tentang Penanggulangan Pemasungan Pada Orang Dengan Gangguan Jiwa; 2017. https://doi.org/10.20884/1.jih.2018.4.2.115

4. Phelan D, Molero P, Martínez-González MA, Molendijk M. Magnesium and mood disorders: Systematic review and meta-analysis. BJPsych Open. 2018;4(4):167-79. https://doi. org/10.1192/bjo.2018.22 PMid:29897029

5. Noronha JL, Matuschak GM. Magnesium in critical illness: Metabolism, assessment, and treatment. J Crit Care. 2001;15:36-40.

6. Immanuel S, Iriani A. The reference range of serum, plasma, and erythrocyte magnesium. Med J Indones. 2006;15:229-35. https://doi.org/10.13181/mji.v15i4.246

7. Nechifor M. Magnesium in psychoses (schizophrenia and bipolar disorders). In: Vink R, Nechifor M, editors. Magnesium in the Central Nervous System. Romania: University of Adelaide Press; 2011. p. 303-12. https://doi.org/10.1017/ upo9780987073051.023

8. Ordak M, Matras J, Muszynska E, Nasierowski T, BujalskaZadrozny M. Magnesium in Schizophrenia, Pharmacological Reports, Report No. 44. Poland: Medical University of Warsaw, Department of Pharmacodynamics; 2017. https://doi. org/10.1016/j.pharep.2017.03.022

9. Gueux E, Duchene-Marullaz P, Rayssiguier Y. Plasma and erythrocyte magnesium levels in a French population. Mag Bull. 1988;10(1):77-80.

10. Leucht S, Samara M, Heres S, Patel MX, Furukawa T, Cipriani A et al. Dose equivalents for second-generation antipsychotic drugs: The classical mean dose method. Schizophr Bull.
2015;41(6):1397-402. https://doi.org/10.1093/schbul/sbv037 PMid:25841041

11. Dahlan MS, editor. Statistik Untuk Kedokteran dan Kesehatan. $1^{\text {st }}$ ed. Jakarta: Sagung Seto; 2014.

12. Association AP, editors. Diagnostic and Statistical Manual and Mental Disorders DSM-5. $5^{\text {th }}$ ed. London: American Psychiatric Publishing; 2013.

13. Buoli M, Caldiroli A, Panza G, Altamura AC. Prominent clinical dimension, 71 duration of illness and treatment response in schizophrenia: A naturalistic study. Korean Neuropsychiatr Assoc 2012;1(9):354-60. https://doi.org/10.4306/pi.2012.9.4.354

14. Gogtay N, Vya NS, Testa R, Wood SJ, Pantelis C. Age of onset of schizophrenia: Perspectives from structural neuroimaging studies. Schizophr Bull. 2011;37(3):504-13. https://doi. org/10.1093/schbul/sbr03

PMid:21505117

15. Huang J, Chiovenda A, Shao Y, Ma H, Li H, Good MD. Low level of knowledge regarding diagnosis and treatment among inpatients with schizophrenia in shanghai. Neuropsychiatr Dis Treat. 2018;14(1):185-91. https://doi.org/10.2147/ndt.s152917 PMid:29379291

16. De Pinho LG, Pereira A, Chaves C. Influence of sociodemographic and clinical characteristics on the quality of life of patients with schizophrenia. J Sch Nurs Univ Sao Paulo. 2017;1(1):1-7.

17. Jahn-Dechent W, Ketteler M. Magnesium basics. Clin Kidney J. 2012;5 Suppl 1:i3-14.

PMid:26069819

18. Severance EG, Prandovszky E, Castiglione J, Yolken RH. Gastroenterology issues in schizophrenia: Why the gut matters. Curr Psychiatry Rep. 2015;17(5):27. https://doi.org/10.1007/ s11920-015-0574-0 PMid:25773227

19. Banskota S, Ghia JE, Khan W. Serotonin in the gut: Blessing or a curse. J Biochim Can. 2018;161:56-64. https://doi. org/10.1016/j.biochi.2018.06.008

20. Fukuda K. 5-HTP hypothesis of schizophrenia. Med Hypotheses. 2014;82(1):20-3. PMid:24280562

21. Stahl SM. Psychosis and schizophrenia. In: Stahl's Essential Psychopharmacology: Neuroscientific Basis and Practical Application. $4^{\text {th }}$ ed. Cambridge: Cambridge University Press; 2013. 